\title{
Role of AM Fungi in Mitigating Moisture Stress in Soybean (Glycine max L. Merill)
}

\author{
Suma R. Konnur*, P. Jones Nirmalnath and K.S. Jagadeesh
}

Department of Agricultural Microbiology, College of Agriculture, Dharwad, University of Agricultural Sciences, Dharwad, Karnataka, India

*Corresponding author

\section{Keywords}

Moisture stress, AMF, Biophysical parameters,

Osmolytes,

Antioxidant activity

Article Info

Accepted:

12 June 2019

Available Online:

10 July 2019

\section{A B S T R A C T}

An attempt was made to screen forty native AM fungal isolates from the soybean rhizosphere of Belagavi and Dharwad districts based on their peroxidise activity and total dry matter accumulation in soybean under the restricted water regime of -500 $\mathrm{kPa}$. Top three fungal isolates viz., UASDAMFS15, UASDAMFS25 and UASDAMFS36 tentatively identified as G. maculosum, $G$. manihotis and $G$. globiferum respectively. For pot culture studies three irrigation regimes were maintained viz., $-33 \mathrm{kPa}-500 \mathrm{kPa}$ and $-1000 \mathrm{kPa}$. An experiment was laid out in completely randomized design with factorial concept. There were twenty one treatments and four replications. In general, AMF inoculations reduced the moisture stress in plants significantly. Among them, UASDAMF consortium and UASDAMF soybean consortium significantly increased the stomatal conductance, photosynthetic activity, transpiration rate, ACC deaminase activity and leghaemoglobin content in the plants. Further, UASDAMF consortium and UASDAMF soybean consortium greatly reduced the leaf temperature, proline, glycine betaine content, peroxidase and PALase activity in the plants compared to single inoculants and UIC. Thus, our preliminary findings are indicative of the effectiveness of AMF in protecting plants from water stress and hence can be a promising strategy to develop a biological tool for mitigation of moisture stress.

\section{Introduction}

It is generally known that soil productivity depends on its physical and chemical properties. Water is an essential parameter for plant growth and development as well as much concern has been expressed in the recent year towards increase in the area of arid regions of the world. Crop productivity in arid regions depends on the length, magnitude and stage of the plant that is affected by moisture stress.

Drought is a serious problem in the state, with about two-thirds having $750 \mathrm{~mm}$ or less annual rainfall. The severity and the extent of drought not only depend on low rainfall but also on the other hydro-meteorological factors like soil moisture, infiltration and moisture retention capacity of the soil. 
To ameliorate the adverse affects of moisture stress, microorganisms could play an important role in adaptation strategies and increase of tolerance to abiotic stresses in agricultural plants, such as plant growth promoting microorganisms which colonizes the portion of soil attached to the root surface and influenced by root exudates termed as rhizosphere soil (Bent, 2006; Lugtenberg and Kamilova, 2009). Some of the beneficial microorganisms can also enter into the root system of their hosts and enhance their beneficial effects with an endophytic lifestyle like plant growth promoting fungi (PGPF) such as arbuscular mycorrhizal fungi (AMF) as well as plant growth promoting rhizobacteria (Das and Varma, 2009).

Among them mycorrhizal association is emerging as one of the efficient ways to combat stress effects and thereby making plants to grow better under drought environment (Gianinazzi et al., 2010). The AMF hyphae can absorb water, as well as improve the capacity of the root system to extract soil water by giving it access to enter pores that are too small for root hairs to access. Furthermore, AMF regulate the plant nutrient uptake, stomatal conductance, leaf water potential, photosynthesis and transpiration rate ( $\mathrm{Li}$ et al., 2014). Besides this, symbiotic association could also induce production of growth promoting hormones; antioxidative enzymes improve plant root architecture (Wu et al., 2012) and soil properties. Taken together, all these events help the plants to produce significantly higher yields under stressful condition.

\section{Materials and Methods}

\section{Experimental design and statistical analysis}

The data were subjected to analysis following Completely Randomised Design (CRD) as defined by Gomez and Gomez (1984) with two factorials. There were twenty one treatments and each treatment was replicated four times. First factor was six AM fungus treatments, one uninoculated control and second factor was three irrigation regimes i.e, $\mathrm{I}_{1}(-33 \mathrm{kPa}), \mathrm{I}_{2}(-500 \mathrm{kPa})$ and $\mathrm{I}_{3}(-1000 \mathrm{kPa})$. This was measured by using Pressure plate and membrane apparatus. Moisture in the pots was maintained by measuring daily evapotranspiration rate. Pot trials were conducted in the poly house at department of agricultural microbiology, University of Agricultural Sciences, Dharwad.

\section{Soil and biological material}

The soil which used for the experiment was Black soil and it was collected from University of Agricultural Sciences, Dharwad farm. The AM fungal species used were UASDAMFS15, UASDAMFS25 and UASDAMFS36 which were isolated from the Dharwad and Belgaum districts. UASDAMF soybean consortium was prepared by mixing of all three native AM fungal isolates. Reference strain and UASDAMF consortium AM fungal inoculations were collected from the Department of Agricultural Microbiology, UAS, Dharwad. The pots were filled with three kg of black soil and AMF inoculum @ $50 \mathrm{~g} \mathrm{pot}^{-1}$ was mixed thoroughly with the top 10 to $15 \mathrm{~cm}$ of the soil.

\section{Parameters measured}

\section{Biophysical parameters (Infra-Red Gas Analyser)}

Measurement of photosynthetic rate, stomatal conductance, rate of transpiration and leaf temperature were made on the top fully expanded leaf at different locations by using a portable photosynthesis system (LI-6400 LICOR, Nebraska, Lincoln USA,). These measurements were made between 10.00 am to 12.00 noon of the day. 


\section{Proline}

Estimation of Proline was done by following the procedure of Bates et al., (1973).

Plant material of $0.5 \mathrm{~g}$ was homogenized in 10 $\mathrm{ml}$ of 3 per cent aqueous sulphosalicylic acid. Filtered the homogenate through Whatman No.2 filter paper and $2 \mathrm{ml}$ of filtrate was taken in a test tube and $2 \mathrm{ml}$ of glacial acetic acid and $2 \mathrm{ml}$ acid ninhydrin was added. Heated it in the boiling water bath for $1 \mathrm{~h}$. The reaction was terminated by placing the tube in ice bath. $4 \mathrm{ml}$ toluene was added to the reaction mixture and stirred well for 20-30 sec. Toluene layer was seperated and warmed it to room temperature. The red colour intensity was measured at $520 \mathrm{~nm}$. Series of standard with pure proline in a similar way was done and prepared a standard curve. Amount of proline in the test sample was found out from the standard curve.

\section{Glycine- Betaine}

Glycine-Betaine content in plant was estimated by following the procedure of Greive and Grattan (1983).

Estimation was done using dried leaf powder. Finely powdered plant material $(0.5 \mathrm{~g})$ was mechanically shaken with $20 \mathrm{ml}$ of deionized water for $48 \mathrm{~h}$ at $25{ }^{\circ} \mathrm{C}$. The samples were then filtered and the filtrate was stored in freezer until analysis. Thawed extracts was diluted 1:1 with $2 \mathrm{~N}$ sulfuric acid. Aliquot (0.5 $\mathrm{ml}$ ) was measured into test tube and cooled in ice water for $1 \mathrm{~h}$. Cold potassium iodide $(0.2$ $\mathrm{ml}$ ) was added and the mixture was gently mixed with vortex mixture. The samples were stored at $0-4{ }^{\circ} \mathrm{C}$ for $16 \mathrm{~h}$. After the expiring of the period samples were transferred to centrifuge tubes and then centrifuged at $10,000 \mathrm{rpm}$ for $15 \mathrm{~min}$ at $0{ }^{\circ} \mathrm{C}$. The supernatant was carefully aspirated with $1 \mathrm{ml}$ micropipette. As the solubility of the periodite complexes in the acid reaction mixture increases markedly with temperature it is important that the tubes be kept cold until the periodite complex is separated from acid media. The periodite crystals were dissolved in $9 \mathrm{ml}$ of 1,2-dichloro ethane (reagent grade). Vigorous vortex mixing was done to effect complete solubility in developing solvent. After 2.0-2.5 h the absorbance was measured at $365 \mathrm{~nm}$ with UV/visible spectrophotometer. Reference standard of GB (50-200 mg ml${ }^{-1}$ ) was prepared in $2 \mathrm{~N}$ sulfuric acid and the procedure for sample estimation was followed.

\section{Peroxidase activity}

Peroxidase activity was done by the following the procedure given by Maehly and Chance (1954). A $0.5 \mathrm{~g}$ of fresh leaf sample was weighed and ground well in a mortar with little quantity of chilled phosphate buffer at pH 6.6 and filtered through a double layered muslin cloth to remove the pulp, made up to $25 \mathrm{ml}$ and centrifuged for 30 minutes at 2,000 rpm at $4{ }^{\circ} \mathrm{C}$. The clear extract was used as enzyme source. The same enzyme was used for the estimation of soluble protein. $3 \mathrm{ml}$ of $0.05 \mathrm{M}$ guaiacol solution was pipetted out into a test tube to which $0.1 \mathrm{ml}$ of enzyme extract was added. Then $0.5 \mathrm{ml}$ of 1 per cent hydrogen peroxidase was added, mixed the contents rapidly and the absorbance was measured in calorimeter at $470 \mathrm{~nm}$ at an interval of 20 seconds.

Enzyme activity was calculated by taking the average difference of $\mathrm{O}$. D. (optical density) between two consecutive time intervals and enzyme activity was expressed in terms of $\Delta \mathrm{OD} \mathrm{sec} \mathrm{mg}^{-1}$ protein (i.e. specific activity).

\section{ACC deaminase activity}

ACC deaminase activity was estimated by the following the procedure of Penrose and Glick (2003). 
ACC (1-Aminocyclopropane-1-carboxylate) deaminase activity was determined by measuring the production of $\alpha$ - ketobutyrate and ammonia generated by the cleavage of ACC deaminase (Penrose and Glick, 2003). The bacterial cells were harvested by centrifugation at $3000 \mathrm{rpm}$ for $5 \mathrm{~min}$, washed twice with $0.1 \mathrm{M}$ Tris- $\mathrm{HCl}(\mathrm{pH}$ 7.5) and resuspended in $200 \mu \mathrm{l}$ of $0.1 \mathrm{M}$ Tris- $\mathrm{HCl}(\mathrm{pH}$ 8.5 ). The cells were labilized by adding 5 per cent toluene and then vortexed at the highest speed for 30 seconds. $50 \mu 1$ of labilized cell suspension were incubated with $5 \mu 1$ of $0.3 \mathrm{M}$ ACC in an Eppendof tube at $28{ }^{\circ} \mathrm{C}$ for $30 \mathrm{~min}$.

The negative control for this assay was included of $50 \mu \mathrm{l}$ of $0.1 \mathrm{M}$ Tris- $\mathrm{HCl}(\mathrm{pH} 8.5)$ with $5 \mu 1$ of $0.3 \mathrm{M} \mathrm{ACC}$. The samples were mixed thoroughly with $500 \mu \mathrm{l}$ of $0.56 \mathrm{~N} \mathrm{HCl}$ by vortexing and the cell debris were removed by centrifugation at $10,000 \mathrm{rpm}$ for $5 \mathrm{~min}$. A $500 \mu \mathrm{l}$ aliquot of the supernatant was transferred to a glass test tube and mixed with $400 \mu 1$ of $0.56 \mathrm{~N} \mathrm{HCl}$ and $150 \mu \mathrm{l}$ of DNF solution $(0.1 \mathrm{~g} \mathrm{2,4-dinitrophenylhydrazine} \mathrm{in}$ $100 \mathrm{ml}$ of $2 \mathrm{~N} \mathrm{HCl}$ ) and the mixture was incubated at $28{ }^{\circ} \mathrm{C}$ for $30 \mathrm{~min}$. One $\mathrm{ml}$ of $2 \mathrm{~N}$ $\mathrm{NaOH}$ was added to the sample before measuring the absorbance at $540 \mathrm{~nm}$.

The concentration of $\alpha$-ketobutyrate in each sample was determined by comparison with a standard curve generated as follows: $500 \mu 1 \alpha-$ ketobutyrate solutions of $0,0.01,0.05,0.1$, $0.2, \quad 0.5, \quad 0.75$ and $1 \mathrm{mM}$ was mixed respectively with $400 \mu \mathrm{l}$ of $0.56 \mathrm{~N} \mathrm{HCl}$ and $150 \mu \mathrm{l} \mathrm{DNF}$ solution. One $\mathrm{ml}$ of $2 \mathrm{~N} \mathrm{NaOH}$ was added and the absorbance versus $\alpha$ ketobutyrate concentration $(\mathrm{mM})$ was used to construct a standard curve.

\section{PALase activity (Phenylalanine Ammonia Lyase)}

PALase activity was done by following the procedure of Dickerson et al., (1984).
Plant sample of one $\mathrm{g}$ was homogenized in 3 $\mathrm{ml}$ of ice cold $0.1 \mathrm{M}$ sodium borate buffer, $\mathrm{pH}$ 7.0 , containing $1.4 \mathrm{mM}$ of 2-mercaptoethanol and $50 \mathrm{mg}$ of insoluble poly vinyl pyrrolidone (PVP). The resulting extract was filtered through cheese cloth and the filtrate was centrifuged at $20,000 \mathrm{rpm}$ for $15 \mathrm{~min}$ at $4{ }^{\circ} \mathrm{C}$ and the supernatant was used as the enzyme source.

PAL activity was determined as the rate of conversion of L-phenylalanine to transcinnamic acid at $290 \mathrm{~nm}$. Sample containing $0.5 \mathrm{ml}$ of enzyme extract was incubated with $0.5 \mathrm{ml}$ of $0.1 \mathrm{M}$ borate buffer $\mathrm{pH} 8.8$ and 9.5 $\mathrm{ml}$ of $12 \mathrm{mM}$ L-phenylalanine in the same buffer for $30 \mathrm{~min}$ at $30{ }^{\circ} \mathrm{C}$. The amount of trans-cinnamic acid synthesized was calculated. Enzyme activity was expressed on fresh weight basis as $\mathrm{n}$ mol trans-cinnamic acid $\mathrm{min}^{-1} \mathrm{mg}^{-1}$ of sample.

\section{Leghaemoglobin content}

Leghaemoglobin content was estimated by the following the procedure of Wilson and Reisenauer (1963).

Nodules of $0.2 \mathrm{~g}$ was taken in $600 \mu \mathrm{l}(1 \mathrm{~g}$ nodules in $3 \mathrm{ml}$ ) Drabkin solution in a micro centrifuge tube and crushed properly. The suspension was centrifuged @ 1,500 rpm for 15 minutes. The supernatant was collected in fresh micro centrifuge tube. The pellet was similarly reextracted two or more times while collecting the supernatant in the same tube everytime.

Then, the volume of the supernatant was made up to $2 \mathrm{ml}$ and centrifuged again @ 20,000 rpm for 20 minutes. Absorbance of the supernatant was recorded at $540 \mathrm{~nm}$. The concentration of legheamoglobin was calculated according to the standard curve (obtained using Bovine Serum Haemoglobin as standard). 


\section{Results and Discussion}

\section{Screening of forty native isolates}

Forty native isolates were screened for peroxidase activity and total dry matter accumulation under $-500 \mathrm{kPa}$ water regime. Among forty native isolates, UASDAMFS15, UASDAMFS25 and UASDAMFS36 recorded low peroxidase activity and higher dry matter accumulation. Based on these parameters top three isolates i.e., UASDAMFS15, UASDAMFS25 and UASDAMFS36 were taken for further pot culture experiment.

\section{Pot culture studies}

Biophysical parameters of soybean as influenced by AMF

The data on biophysical parameters of soybean plants as influenced by different AM fungal isolates are presented in Table 1.

Stomatal conductance, photosynthetic rate and transpiration rate were maximum in UASDAMF soybean consortium, UASDAMF consortium, UASDAMFS25, UASDAMFS36, G. fasciculatum (reference strain) and UASDAMFS15 over uninoculated control plants at all the moisture regimes. Leaf temperature was maximum in non mycorrhized plants. Low leaf temperature was recorded with mycorrhized plants UASDAMF soybean consortium, UASDAMF consortium, UASDAMFS25, UASDAMFS36, $G$. fasciculatum (reference strain) and UASDAMFS15.

\section{Proline and glycine -betain content}

UASDAMF consortium and UASDAMF soybean consortium, single isolates viz., UASDAMFS25, UASDAMFS36, $G$. fasciculatum, UASDAMFS15 decreased the proline and glycine -betaine content in plants, over non mycorrhized soybean plants at at all the moisture regimes (Table 2).

\section{Antioxidant activities}

Peroxidase and PALase activites were decreased upon inoculation of mycorrhiza. Non mycorrhized plants showed high peroxidase and PALase activity at all water regimes. ACC deaminase activity was highest in mycorrhized plants compared to non mycorrhized plants at all the water regimes (Table 3).

\section{Leghaemoglobin content}

Leghaemoglobin content was maximum in the plants inoculated with UASDAMF soybean consortium, UASDAMF consortium, UASDAMFS25, UASDAMFS36, $G$. fasciculatum (reference strain) and UASDAMFS15 over non mycorrhized plants at all the moisture regimes (Table 4).

Plants face various abiotic stresses in adverse environmental conditions. Abiotic stress is a complex process against which signals the cells to adapt themselves at the molecular, biochemical and physiological levels. Drought, induced by climate change or depletion of ground water, was arguably the major agent limiting the crop growth and productivity and poses biggest challenge for the global food security (Rajkumar et al., 2013). Drought tolerance in crop plants is multidimensional ranging from morphological, physiological to molecular level (Lopes et al., 2011). Although plants could adapt a number of strategies to alleviate stress effects, mycorrhizal association is emerging as one of the efficient ways to combat stress effects in plants (Gianinazzi et al., 2010). In fact, several studies have shown the importance of use of microbial inoculants, especially the AMF in alleviating drought stress in crop plants (Zoppellari et al., 2014). 
Table.1 Biophysical parameters as influenced by selected AM fungal isolates at different moisture levels (Infra-Red Gas Analyser) at 30 DAS

\begin{tabular}{|c|c|c|c|c|c|c|c|c|c|c|c|c|c|c|c|c|}
\hline \multirow{2}{*}{$\begin{array}{l}\text { Treatment } \\
\text { AMF }\end{array}$} & \multicolumn{4}{|c|}{$\begin{array}{l}\text { Stomatal Conductance } \\
\left(\mu \mathrm{mol} / \mathrm{CO}_{2} / \mathrm{m}^{2} / \mathrm{sec}\right)\end{array}$} & \multicolumn{4}{|c|}{$\begin{array}{l}\text { Photosynthetic rate } \\
\quad\left(\mu \mathrm{mol} / \mathrm{m}^{2} / \mathrm{sec}\right)\end{array}$} & \multicolumn{4}{|c|}{ Leaf temperature $\left({ }^{0} \mathrm{C}\right)$} & \multicolumn{4}{|c|}{$\begin{array}{l}\text { Transpiration rate } \\
\left(\mathrm{mmol} / \mathrm{m}^{2} / \mathrm{sec}\right)\end{array}$} \\
\hline & $\mathbf{I}_{\mathbf{1}}$ & $\mathbf{I}_{2}$ & $\mathbf{I}_{3}$ & $\begin{array}{c}\text { Mean } \\
\text { of } A\end{array}$ & $\mathbf{I}_{\mathbf{1}}$ & $\mathbf{I}_{2}$ & $\mathbf{I}_{3}$ & $\begin{array}{c}\text { Mean } \\
\text { of } \mathrm{A}\end{array}$ & $\mathbf{I}_{\mathbf{1}}$ & $\mathbf{I}_{2}$ & $\mathbf{I}_{3}$ & $\begin{array}{c}\text { Mean } \\
\text { of } A\end{array}$ & $\mathbf{I}_{\mathbf{1}}$ & $\mathbf{I}_{2}$ & $\mathbf{I}_{3}$ & $\begin{array}{c}\text { Mean } \\
\text { of A }\end{array}$ \\
\hline UASDAMFS15 & 0.22 & 0.16 & 0.15 & 0.18 & 27.00 & 24.00 & 22.61 & 24.53 & 27.67 & 29.38 & 29.91 & 28.98 & 4.23 & 4.22 & 4.16 & 4.20 \\
\hline UASDAMFS25 & 0.24 & 0.20 & 0.18 & 0.20 & 27.81 & 26.33 & 23.64 & 25.92 & 25.89 & 27.61 & 29.83 & 27.78 & 4.36 & 4.28 & 4.21 & 4.28 \\
\hline UASDAMFS36 & 0.23 & 0.19 & 0.16 & 0.19 & 27.60 & 25.93 & 22.94 & 25.49 & 26.14 & 27.75 & 29.85 & 27.91 & 4.30 & 4.24 & 4.12 & 4.22 \\
\hline $\begin{array}{l}\text { UASDAMF Soybean } \\
\text { Consortium }\end{array}$ & 0.47 & 0.45 & 0.35 & 0.42 & 29.09 & 27.82 & 27.04 & 27.98 & 24.87 & 26.53 & 28.73 & 26.71 & 4.63 & 4.60 & 4.28 & 4.50 \\
\hline $\begin{array}{l}\text { G. fasciculatum } \\
\text { (reference strain) }\end{array}$ & 0.23 & 0.17 & 0.15 & 0.18 & 27.25 & 25.79 & 22.74 & 25.26 & 26.74 & 28.13 & 29.88 & 28.25 & 4.27 & 4.23 & 4.15 & 4.21 \\
\hline $\begin{array}{l}\text { UASDAMF } \\
\text { Consortium }\end{array}$ & 0.38 & 0.37 & 0.26 & 0.33 & 28.24 & 27.59 & 26.58 & 27.47 & 25.35 & 27.10 & 29.53 & 27.32 & 4.48 & 4.34 & 4.28 & 4.36 \\
\hline UIC & 0.20 & 0.15 & 0.11 & 0.15 & 24.60 & 22.67 & 21.32 & 22.86 & 28.50 & 30.49 & 30.95 & 29.98 & 4.21 & 4.19 & 4.14 & 4.18 \\
\hline \multirow[t]{2}{*}{ Mean of B } & 0.28 & 0.24 & 0.19 & & 27.37 & 25.73 & 23.83 & & 26.45 & 28.14 & 29.81 & & 4.34 & 4.30 & 4.19 & \\
\hline & \multicolumn{2}{|c|}{ S.Em. \pm} & \multicolumn{2}{|c|}{ C.D. $(p=0.01)$} & \multicolumn{2}{|c|}{ S.Em. \pm} & \multicolumn{2}{|c|}{ C.D. $(p=0.01)$} & \multicolumn{2}{|c|}{ S.Em. \pm} & \multicolumn{2}{|c|}{ C.D. $(p=0.01)$} & \multicolumn{2}{|c|}{ S.Em. \pm} & \multicolumn{2}{|c|}{ C.D. $(p=0.01)$} \\
\hline C.D. of M (AMF) & \multicolumn{2}{|c|}{0.01} & \multicolumn{2}{|c|}{0.29} & \multicolumn{2}{|c|}{0.22} & \multicolumn{2}{|c|}{0.67} & \multicolumn{2}{|c|}{0.19} & \multicolumn{2}{|c|}{0.57} & \multicolumn{2}{|c|}{0.01} & \multicolumn{2}{|c|}{0.04} \\
\hline C.D. of S (Moisture) & \multicolumn{2}{|c|}{0.06} & \multicolumn{2}{|c|}{0.18} & \multicolumn{2}{|c|}{0.09} & \multicolumn{2}{|c|}{0.28} & \multicolumn{2}{|c|}{0.16} & \multicolumn{2}{|c|}{0.48} & \multicolumn{2}{|c|}{0.02} & \multicolumn{2}{|c|}{0.09} \\
\hline $\begin{array}{l}\text { C.D. of A } \times \text { B }(A M \\
\text { fungi } \times \text { Different } \\
\text { moisture levels })\end{array}$ & \multicolumn{2}{|c|}{0.01} & \multicolumn{2}{|c|}{0.05} & \multicolumn{2}{|c|}{0.25} & \multicolumn{2}{|c|}{0.74} & 0. & & & 20 & & & & 07 \\
\hline
\end{tabular}

$\begin{array}{cl}\text { Note - } & \mathrm{I}_{1} \text { - Irrigation regime } 1(-33 \mathrm{kPa}) \\ & \mathrm{I}_{2} \text {-Irrigation regime } 2(-500 \mathrm{kPa}) \\ & \mathrm{I}_{3} \text {-Irrigation regime } 3(-1000 \mathrm{kPa}) \\ \text { UASDAMF soybean Consortium (UASDAMFS15 + UASDAMFS25 + UASDAMFS36) }\end{array}$ 
Table.2 Proline and Glycine-Betaine content of soybean at different moisture levels at 30 DAS

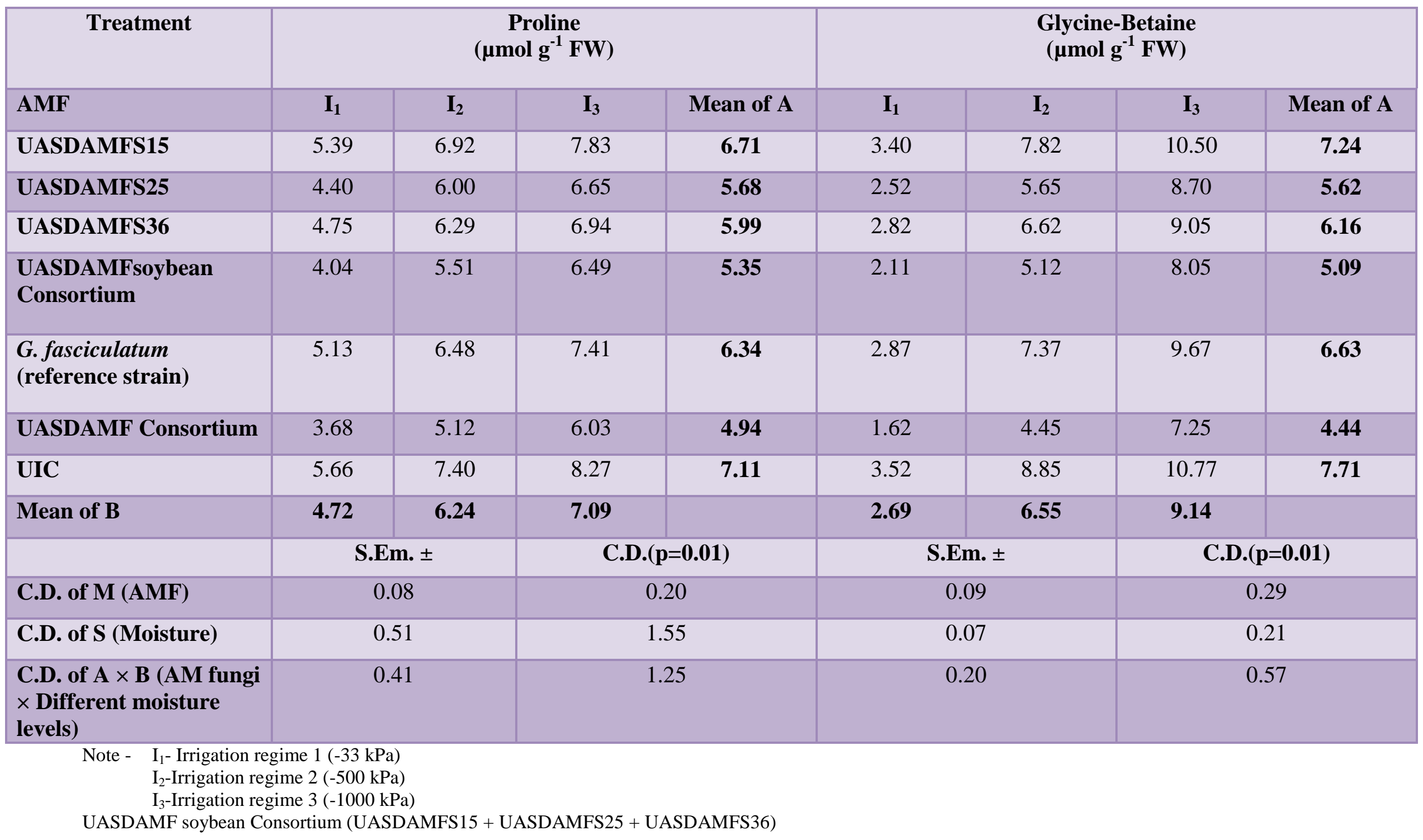


Table.3 Influenced of selected AM fungal isolates on Peroxidase, ACC deaminase and PAL activities at different moisture levels at 30 DAS

\begin{tabular}{|c|c|c|c|c|c|c|c|c|c|c|c|c|}
\hline \multirow{2}{*}{$\begin{array}{l}\text { Treatment } \\
\text { AMF }\end{array}$} & \multicolumn{4}{|c|}{$\begin{array}{c}\text { Peroxidase } \\
\left(\mathbf{U ~ m g}^{-1} \text { protein }\right)\end{array}$} & \multicolumn{4}{|c|}{$\begin{array}{c}\text { ACC deaminase } \\
\left(\text { nmol } \alpha \text { ketobutyrate } g^{-1}\right. \\
\left.\text { biomass } h^{-1}\right)\end{array}$} & \multicolumn{4}{|c|}{$\begin{array}{c}\text { PAL (Phenylalanine Ammonia } \\
\text { Lyase) } \\
\text { (n mol transcinnamic acid } \\
\text { min }^{-1} \mathrm{mg}^{-1} \text { sample) }\end{array}$} \\
\hline & $\mathbf{I}_{1}$ & $\mathbf{I}_{2}$ & $\mathbf{I}_{3}$ & $\frac{\text { Mean of }}{A}$ & $\mathbf{I}_{1}$ & $\mathbf{I}_{2}$ & $\mathbf{I}_{3}$ & $\begin{array}{c}\text { Mean of } \\
\text { A }\end{array}$ & $\mathbf{I}_{1}$ & $\mathbf{I}_{2}$ & $\mathbf{I}_{3}$ & $\frac{\text { Mean of }}{\text { A }}$ \\
\hline UASDAMFS15 & 1.42 & 4.51 & 8.44 & 4.79 & 6.07 & 9.38 & 10.40 & 8.61 & 1.90 & 3.95 & 4.26 & 3.37 \\
\hline UASDAMFS25 & 1.28 & 4.09 & 7.81 & 4.39 & 7.03 & 9.93 & 11.04 & 9.33 & 1.67 & 3.62 & 4.30 & 3.19 \\
\hline UASDAMFS36 & 1.35 & 4.14 & 7.95 & 4.48 & 6.92 & 9.76 & 11.03 & 9.23 & 1.68 & 3.56 & 4.50 & 3.24 \\
\hline $\begin{array}{l}\text { UASDAMF soybean } \\
\text { Consortium }\end{array}$ & 1.27 & 3.79 & 7.09 & 4.05 & 8.06 & 10.09 & 12.18 & 10.11 & 1.59 & 2.80 & 3.65 & 2.68 \\
\hline $\begin{array}{l}\text { G. fasciculatum } \\
\text { (reference strain) }\end{array}$ & 1.41 & 4.25 & 8.29 & 4.65 & 6.23 & 9.71 & 10.93 & 8.95 & 1.95 & 3.65 & 4.31 & 3.30 \\
\hline $\begin{array}{l}\text { UASDAMF } \\
\text { Consortium }\end{array}$ & 1.07 & 3.38 & 6.92 & 3.79 & 7.79 & 9.97 & 12.11 & 9.95 & 1.50 & 3.10 & 3.80 & 2.80 \\
\hline UIC & 1.77 & 5.49 & 9.86 & 5.71 & 5.89 & 9.02 & 10.73 & 8.54 & 1.90 & 3.87 & 4.77 & 3.51 \\
\hline \multirow[t]{2}{*}{ Mean of B } & 1.36 & 4.23 & 8.05 & & 6.85 & 9.69 & 11.20 & & 1.74 & 3.50 & 4.22 & \\
\hline & \multicolumn{2}{|c|}{ S.Em. \pm} & \multicolumn{2}{|c|}{ C.D. $(p=0.01)$} & \multicolumn{2}{|c|}{ S.Em. \pm} & \multicolumn{2}{|c|}{ C.D. $(p=0.01)$} & \multicolumn{2}{|c|}{ S.Em. \pm} & \multicolumn{2}{|c|}{ C.D. $(p=0.01)$} \\
\hline C.D. of M (AMF) & \multicolumn{2}{|c|}{0.05} & \multicolumn{2}{|c|}{0.20} & \multicolumn{2}{|c|}{0.04} & \multicolumn{2}{|r|}{0.20} & \multicolumn{2}{|c|}{0.14} & \multicolumn{2}{|c|}{0.43} \\
\hline C.D. of S (Moisture) & \multicolumn{2}{|c|}{0.21} & \multicolumn{2}{|c|}{0.43} & \multicolumn{2}{|c|}{0.05} & \multicolumn{2}{|r|}{0.15} & \multicolumn{2}{|c|}{0.10} & \multicolumn{2}{|c|}{0.28} \\
\hline $\begin{array}{l}\text { C.D. of A } \times \text { B }(A M \\
\text { fungi } \times \text { Different } \\
\text { moisture levels })\end{array}$ & \multicolumn{2}{|c|}{0.12} & \multicolumn{2}{|c|}{0.38} & \multicolumn{2}{|c|}{0.01} & \multicolumn{2}{|r|}{0.04} & \multicolumn{2}{|c|}{0.26} & \multicolumn{2}{|c|}{0.76} \\
\hline
\end{tabular}

Note - $\mathrm{I}_{1}$ - Irrigation regime $1(-33 \mathrm{kPa})$

$\mathrm{I}_{2}$-Irrigation regime $2(-500 \mathrm{kPa})$

$\mathrm{I}_{3}$-Irrigation regime $3(-1000 \mathrm{kPa})$

UASDAMF soybean Consortium (UASDAMFS15 + UASDAMFS25 + UASDAMFS36) 
Table.4 Nodule parameters as influenced by selected AM fungal isolates at different moisture levels at 45 DAS

\begin{tabular}{|c|c|c|c|c|c|c|c|c|c|c|c|c|}
\hline Treatment & \multicolumn{12}{|c|}{ Nodule parameters } \\
\hline & \multicolumn{4}{|c|}{ Nodule number } & \multicolumn{4}{|c|}{$\begin{array}{l}\text { Nodule dry weight } \\
\qquad\left(\text { g plant }^{-1}\right)\end{array}$} & \multicolumn{4}{|c|}{$\begin{array}{l}\text { Leghaemoglobin content } \\
\text { (mg g } \mathrm{m}^{-1} \text { FW nodules) }\end{array}$} \\
\hline AMF & $\mathbf{I}_{1}$ & $\mathbf{I}_{2}$ & $\mathbf{I}_{3}$ & $\begin{array}{c}\text { Mean } \\
\text { of A }\end{array}$ & $\mathbf{I}_{1}$ & $\mathbf{I}_{2}$ & $\mathbf{I}_{3}$ & $\begin{array}{c}\text { Mean } \\
\text { of A }\end{array}$ & $\mathbf{I}_{1}$ & $\mathbf{I}_{2}$ & $\mathbf{I}_{3}$ & $\begin{array}{c}\text { Mean } \\
\text { of A }\end{array}$ \\
\hline UASDAMFS15 & 26.84 & 21.27 & 13.92 & 20.67 & 1.74 & 0.71 & 0.51 & 0.98 & 0.50 & 0.19 & 0.18 & 0.29 \\
\hline UASDAMFS25 & 34.66 & 28.10 & 17.45 & 26.73 & 1.80 & 0.87 & 0.55 & 1.07 & 0.55 & 0.26 & 0.19 & 0.33 \\
\hline UASDAMFS36 & 30.89 & 24.81 & 16.22 & 23.97 & 1.80 & 0.84 & 0.52 & 1.05 & 0.54 & 0.23 & 0.19 & 0.32 \\
\hline $\begin{array}{l}\text { UASDAMF soybean } \\
\text { Consortium }\end{array}$ & 36.44 & 28.59 & 17.48 & 27.50 & 2.12 & 1.13 & 0.54 & 1.26 & 0.69 & 0.36 & 0.24 & 0.43 \\
\hline $\begin{array}{l}\text { G. fasciculatum } \\
\text { (reference strain) }\end{array}$ & 29.61 & 22.79 & 15.19 & 22.73 & 1.76 & 0.81 & 0.51 & 1.02 & 0.51 & 0.22 & 0.17 & 0.30 \\
\hline $\begin{array}{l}\text { UASDAMF } \\
\text { Consortium }\end{array}$ & 39.75 & 31.13 & 20.75 & 30.54 & 2.15 & 1.17 & 0.56 & 1.29 & 0.66 & 0.29 & 0.22 & 0.39 \\
\hline UIC & 25.31 & 20.02 & 13.16 & 19.49 & 0.77 & 0.76 & 0.40 & 0.64 & 0.29 & 0.20 & 0.16 & 0.22 \\
\hline \multirow[t]{2}{*}{ Mean of B } & 31.93 & 25.24 & 16.31 & & 1.73 & 0.90 & 0.51 & & $\mathbf{0 . 5 3}$ & 0.25 & 0.19 & \\
\hline & \multicolumn{2}{|c|}{ S.Em. \pm} & \multicolumn{2}{|c|}{ C.D. $(p=0.01)$} & \multicolumn{2}{|c|}{ S.Em. \pm} & \multicolumn{2}{|c|}{ C.D. $(p=0.01)$} & \multicolumn{2}{|c|}{ S.Em. \pm} & \multicolumn{2}{|c|}{ C.D. $(p=0.01)$} \\
\hline C.D. of M (AMF) & \multicolumn{2}{|c|}{0.43} & \multicolumn{2}{|c|}{1.28} & \multicolumn{2}{|c|}{0.02} & \multicolumn{2}{|c|}{0.07} & \multicolumn{2}{|c|}{0.12} & \multicolumn{2}{|c|}{0.38} \\
\hline C.D. of S (Moisture) & \multicolumn{2}{|c|}{0.38} & \multicolumn{2}{|c|}{1.09} & \multicolumn{2}{|c|}{0.01} & \multicolumn{2}{|c|}{0.04} & \multicolumn{2}{|c|}{0.07} & \multicolumn{2}{|c|}{0.22} \\
\hline $\begin{array}{l}\text { C.D. of } A \times B(A M \\
\text { fungi } \times \text { Different } \\
\text { moisture levels })\end{array}$ & \multicolumn{2}{|c|}{1.01} & \multicolumn{2}{|c|}{2.88} & \multicolumn{2}{|c|}{0.03} & \multicolumn{2}{|c|}{0.11} & \multicolumn{2}{|c|}{0.20} & \multicolumn{2}{|c|}{0.50} \\
\hline
\end{tabular}


The biophysical parameters recorded with the help of IRGA, such as photosynthetic rate and stomatal conductivity, transpiration rate of soybean in the present study have shown maximum values with AMF inoculated plants. This is in agreement with the findings of Ruiz-Lozano et al., (2001). Wherein they have also reported an increased photosynthetic activity, stomatal conductance, transpiration rate and decreasing rate of leaf temperature due to AMF inoculated plants under drought stressed condition. Low leaf temperature was observed due to cooling effect by water which was provided by AMF to plants during stressed condition (RuizLozano and Azcon, 1995).

A lower concentration of proline may be attributed to either greater drought resistance AMF colonized plants under drought stress conditions ( $\mathrm{Wu}$ and Xia, 2006). The amount of proline was found more in non mycorrhizal plants than mycorrhizal plants. This was due to AM fungi which helps the host plant during water stress condition. Mycorrhizal plants synthesize less amount of proline than non mycorrhizal plants. Proline is an important amino acid in plant under drought stress that prevents oxidation of cells from inside. It also regularizes osmotic pressure of plant under drought stress for absorbing water (Bhosale and Shinde, 2011).

Increased glycine betaine with water stress conditions was reduced by the application of AM fungi. This indicates that glycine betaine as an effective compatible solute enhanced by the drought stress. The major role of glycine betaine might be protection of the integrity of the cell membrane from drought stress damage and involvement in osmotic adjustment (Lv et al., 2007).

The lower oxidative damage in the AM plants seems to be a consistent effect of AM symbiosis, regardless of the fungal species involved in the association (Ruiz-Lozano et al., 2001 and Porcel et al., 2003). AMF contribution to plant drought tolerance might also have occurred through drought avoidance mechanisms such as hyphal water uptake (Marulanda et al., 2003) or increased water uptake related to mycorrhizal changes in root morphology (Kothari et al., 1990) or soil structure (Auge et al., 2001a). Such mycorrhizal effects could allow plants to remain more hydrated than non-AM plants as soil dries (Auge et al., 2001b). AM formation contributes to the production of scavenging peroxyl radicals, buffering cellular freeradicals and producing a powerful ROSscavenging system (Ashraf and Foolad, 2007).

Although ethylene is essential for normal growth and development in plants, at high concentration it can be harmful as it induces defoliation and other cellular processes that may lead to reduced crop performance. Using their 1-amino cyclopropane-1-carboxylic acid (ACC) deaminase activity, microorganisms can divert ACC from the ethylene biosynthesis pathway. Thus microorganisms assist in diminishing the accumulation of ethylene levels and reestablish a healthy root system needed to cope with environmental stress (Glick et al., 2007).

The biosynthesis of PALase and have been reported up on pathogenic attack including viruses, tissue wounding, UV irradiation, low temperatures, drought condition, salinity, low levels of nitrogen, phosphate and iron (Ritter and Schulz, 2004; Gholizadeh et al., 2004). Similar results were also found in our experiment where at $-500 \mathrm{kPa}$ and $-1000 \mathrm{kPa}$ irrigation regimes, an increased PALase activity was noticed compared to $-33 \mathrm{kPa}$. Inoculation of AM fungi to plants decreased the PALase activity as plants are less susceptible to stress conditions. UASDAMF soybean consortium showed less PALase 
activity followed by UASDAMF consortium compared to uninoculated control.

\section{References}

Ashraf, M. and Foolad, M. R., 2007, Roles of glycine betaine and proline in improving plant abiotic stress resistance. Environ. Exp. Bot., 59: 206216.

Auge, R. M., 2001b, Water relations, drought and vesicular arbuscular mycorrhizal symbiosis. Mycorrhiza, 11: 3-42.

Auge, R. M., Stodola, A., Tims, J. E. and Saxton, A. M., 2001a, Moisture retention properties of a mycorrhizal soil. Plant Soil, 230: 87-97.

Bates, S., Waldren, P. and Teare, D., 1973, Rapid determination of free proline for water stress studies. Plant Soil, 39: 205207.

Bhosale, K. S. and Shinde, B. P., 2011, Influence of Arbuscular mycorrhizal fungi on proline and chlorophyll content in Zingiber Officinale Rosc grown under water stress. Indian $J$. Fundamental Appl. Life Sci., 3: 172176.

Das, A. and Varma, A., 2009, Symbiosis: The art of living. Symbiotic fungi, Soil Biol., $18-20$.

Dickerson, D. P., Pascholati, S. F., Hagerman, A. E., Butler, L. G. and Nicholson, R. L., 1984, Phenylalanine ammonia lyase and hydroxyl cinnamate CoA ligase in maize mesocotyls inoculated with Helmenthosporium maydis or Helmenthosporium carbonum. Physiol. Plant Pathol., 25: 111-123.

Gholizadeh, A., Kumar, M., Balasubramanyam, A., Sharma, S., Narval, S., Lodha, M. L. and Kapoor, H. C., 2004, Antioxidant activity of antiviral proteins from Celosia cristata L. J. Plant Biochem. Biotechnol., 13: 13-18.
Gianinazzi, S., Gollotte, A., Binet, N., Tuinen, D., Redecker, D. and Wipf, D., 2010, Agroecology: The key role of arbuscular mycorrhizas in ecosystem services. Mycorrhiza, 20: 519-530.

Glick, B. R., Cheng, Z., Czarny, J. and Duan, J., 2007, Promotion of plant growth by ACC deaminase producing soil bacteria. European.J. Plant Pathol., 119: 329339

Gomez, K. A. and Gomez, A. A., 1984, Statistical Procedures for Agricultural Research, $2^{\text {nd }}$ Edition, A WileyInternational Sciences Publ., New York (USA), pp. 125-130.

Greive, C. M. and Grattan, S. R., 1983, Rapid assay for determination of watersoluble quaternary amino compounds. Plant Soil, 70: 303-307.

Kothari, S. K., Marschner, H. and George, E., 1990, Effect of VA mycorrhizal fungi and rhizosphere microorganisms on root and shoot morphology, growth and water relations in maize. New Phytol., 116: 303-311.

Li, T., Lin, G., Zhang, X., Chen, Y., Zhang, S. and Chen, B., 2014, Relative importance of an arbuscular mycorrhizal fungus (Rhizophagus intraradices) and root hairs in plant drought tolerance. Mycorrhiza, 24: 595602.

Lopes, M. S., Araus, J. L., Van, Heerden, P. D. and Foyer, C. H., 2011, Enhancing drought tolerance in $\mathrm{C}_{4}$ crops. J. Exp. Bot., 62: 3135-53.

Lugtenberg, B. and Kamilova, F., 2009, Plant growth promoting rhizobacteria. Annu. Rev. Microbiol., 63: 541-546.

Lv, S., Yang, A., Zhang, K., Wang, L. and Zhang, J., 2007, Increase of glycine betaine synthesis improves drought tolerance in cotton. Mol. Breed., 20: 233-248.

Maehly, A. C. and Chance, B., 1954, The assay of catalases and peroxidases. 
Biochem. Anal., 1: 357-424.

Marulanda, A., Azcon, R. and Ruiz-Lozano, J. M., 2003, Contribution of six arbuscular mycorrhizal fungal isolates to water uptake by Lactuca sativa $\mathrm{L}$. plants under drought stress. Physiologia Plantarum, 119: 526-533.

Penrose, D. M. and Glick, B. R., 2003, Methods for isolating and characterizing ACC deaminase containing plant growth promoting rhizobacteria. Physiol. Plant, 118: 10-15.

Porcel, R., Barea, J. M. and Ruiz-Lozano, J. M., 2003, Antioxidant activities in mycorrhizal soybean plants under drought stress and their possible relationship to the process of nodule senescence. New Phytol., 157: 135-143.

Rajkumar, M., Prasad, M. N., Swaminathan, S. and Freitas, H., 2013, Climate change driven plant metal microbe interactions. Environ. Int., 53: 74-86.

Ritter, H. and Schulz, G. E., 2004, Structural bases for the entrance into the phenypropanoid metabolism catalyzed by phenylalanine ammonia lyase. Plant Cell, 16: 3426-3436.

Ruiz-Lozano, J. M. and Azcon, R., 1995, Hyphal contribution to water uptake in mycorrhizal plants as affected by the fungal species and water status. Physiologia Plantarum, 95: 472-478.

Ruiz-Lozano, J. M., Collados, C., Barea, J. M. and Azcon, R., 2001, Arbuscular mycorrhizal symbiosis can alleviate drought-induced nodule senescence in soybean plants. New Phytol., 151: 493502.

Wilson, D. and Reisenauer, M., 1963, Determination of leghaemoglobin in legume nodules. Anal. Biochem., 6: 2730.

Wu, Q. S. and Xia, R. X., 2006, Arbuscular mycorrhizal fungi influence growth, osmotic adjustment and photosynthesis of citrus under well-watered and water stress conditions. J. Plant Physiol., 163: 417-425.

Wu, S., He, H., Zou, N., Liu, Y., Xiao, J. and Li, Y., 2012, Arbuscular mycorrhizas alter root system architecture of Citrus tangerine through regulating metabolism of endogenous polyamines. Plant Growth Regul., 68: 27-35.

Wu, Z. S., Yue, H., Lu, J. and Li, C., 2012, Characterization of rhizobacterial strains Rs-2 with ACC deaminase activity and its performance in promoting cotton growth under salinity stress. World J. Microbiol. Biotechnol., 28: 2383- 2393.

Zoppellari, F., Malusa, E., Chitarra, W., Lovisolo, C., Spanna, F. and Bardi, L., 2014 Improvement of drought tolerance in Maize (Zea maize L.) by selected rhizospheric microorganisms. Ital. J. Agrometeorol., 18:5-18.

\section{How to cite this article:}

Suma R. Konnur, P. Jones Nirmalnath and Jagadeesh, K.S. 2019. Role of AM Fungi in Mitigating Moisture Stress in Soybean (Glycine max L. Merill). Int.J.Curr.Microbiol.App.Sci. 8(07): 1451-1462. doi: https://doi.org/10.20546/ijcmas.2019.807.173 